\title{
Sexo, desejo e identidades
}

\section{Ana Claudia Figueroa}

Pós-Doutoranda; Universidade Federal do Rio Grande do Sul

wahno@hotmail.com

PRECIADO, Beatriz.

Manifesto contrassexual: práticas

subversivas de identidade sexual. Tradução

de Maria Paula Gurgel Ribeiro. São Paulo:

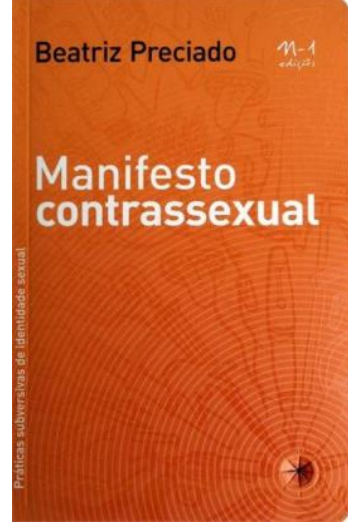

N-1 edições, 2014.

Preciado propõe a declaração de um conceito que desvela a constituição coercitiva da heteronormatividade sexual e, ao mesmo tempo, convida para uma prática de vivência sexual sob nova perspectiva.

0 texto propõe o desejo não mais limitado ao prazer sexual proporcionado aos órgãos reprodutores - que fundamentariam a diferença sexual -, mas uma política do desejo capaz de sexualizar todo o corpo, lugar de resistência a toda normatividade. 0 corpo desejante é mediado tecnologicamente.

Preciado nomeia o livro enquanto diário de viagem de sua percepção das estratégias adotadas em ambos continentes na tarefa da desconstrução tal como proposta por Deleuze e se desdobra em feminismo e em movida queer. "Falar de filosofia queer é viajar guiada só por uma cartografia invisível e, na ausência de solução no horizonte, inventar o Arquivo." (p. 214).

Biografar Paul Beatriz Preciado ajuda a compreender a empreitada do livro/diário. Escrito no período justamente posterior ao seu doutorado, quando recém-chegada a Paris, Manifieste Contra-Sexuel é o seu primeiro livro publicado. 0 livro introduz bases de vivência de sua própria sexualidade; Beatriz está se constituindo no que virá a ser Paul. 
O livro é uma metanarrativa sobre escolhas, sexo, sociedade e globalização das tecnologias do corpo e do prazer. É também o testemunho de uma filósofa, primeiro identificada lésbica e recentemente autodenominada transgênero, que resolve dedicar sua produção teórica à compreensão do papel do desejo na constituição das relações de sociedade.

Preciado estuda práticas de sexualidade que nomeia Práticas de Inversão Contrassexual. Para tanto estuda os manuseios, forma e uso, do Dildo (sexo de plástico). Mais precisamente a Dildotectônica, que é a "[...] identificação de tecnologias de resistência e ruptura à cadeia de produção corpo-prazer-benefício-corpo nas culturas sexuais hétero e queer." (p. 49).

Penso se o livro, antes de virar letra no papel, não aconteceu a partir das experimentações propostas, porque na sua explicitação prática contém uma reflexão social, enquanto interpretação de cultura e sociedade. Por se tratar de experiências masturbatórias e de experimentações das sensações do prazer, a proposição das práticas são muito importantes para compreender os outros textos que compõem o livro.

Preciado observa, nas práticas de uso e manuseio do dildo, que a erótica e o desejo se exprimem em sua capacidade de deslocamento do falo, utilizando as categorias de Judith Butler, que são plasticidade, transferibilidade e expropriabilidade, para expor os elementos que constituem o dildo como a tecnologia sexual que "[...] ocupa lugar estratégico entre as tecnologias de repressão da masturbação e as tecnologias de produção do prazer." (p. 78).

Utiliza o conceito de Suplemento, da obra de Jacques Derrida, para localizar semanticamente o dildo nas suas diversas significações na história do seu uso. Concebido originalmente com utilização terapêutica limitada a situações onde órgãos vivos já não funcionavam, o dildo se transforma prática subversiva da heterossexualidade.

Este é o papel do dildo na significação do prazer e do sexo rumo a superação do binômio sexo/amor, pois seu uso explicita uma reconfiguração do erotismo, que da superação da figura trepador/trepado se constitui experimentação do prazer nunca tomado e, apesar de dado, nunca é real, é reapropriação contínua.

As tecnologias de masturbação, especialmente nos últimos séculos, foram reprimidas e patologizadas pela medicina e, paralelamente, vinculadas à doença feminina conhecida como histeria. A criação do vibrador no espaço terapêutico de cura da histeria, em sua constituição de tecnologia de dominação, é uma ação de higiene doméstica e massagem "familiar". 
O dildo deve ser compreendido para como órgão com funções protéticas, influenciado em sua significação de fase protética após as guerras mundiais, quando foi necessário resolver a perda de membros por tecnologias diversas de construção protética de órgãos do corpo humano (braços, mãos, pernas).

A relação de sexo e reprodução humana, sustentáculos do binarismo heteronormativo, é vista pela expectativa de produção de riquezas dos corpos nomeados pela medicina de hermafroditas. Assim as tecnologias são instrumentos, ao mesmo tempo, limpos e sujos de estruturas de poder pois são espaço de reinvenção da natureza.

Depois de conhecer toda proposição de contrassexualidade no presente no livro, resumida nos treze artigos nas páginas 35 a 43, certamente você está em condições de firmar o Contrato Contrassexual, cujo modelo está disponível nas páginas 45 e 46: "Reconheço-me como um produtor de dildos e como transmissor e difusor de dildos sobre meu próprio corpo e sobre qualquer outro corpo que assine este contrato." (p. 45).

Recebido em 31/03/2016

Aceito em 27/04/2016 